\title{
Forest Moratorium Policy, Deforestation and Forest Degradation in Papua Province
}

\author{
*R Aditya Yudhanegara, Rijanta \\ Department of Architectural and Planning/Master of Urban and Regional Planning, Universitas Gadjah Mada, \\ Email: *adityayudhanegara@mail.ugm.ac.id, rijanta@ugm.ac.id
}

\begin{tabular}{l} 
ARTICLE INFO \\
Article history: \\
Accepted: 22-1 1-2020 \\
Approved: 14-12-2021 \\
\hline Keywords: \\
Policy implementation \\
Forest moratorium \\
Deforestation \\
Forest degradation \\
Local government
\end{tabular}

ARTICLE INFO

Article history:

Accepted: 22-11-2020

\section{A. BACKGROUND}

Climate change has become a global issue in recent decades. One of the main contributors to climate change

\begin{abstract}
On May 20, 2011, the government of the Republic of Indonesia enacted Presidential Instruction (Inpres) number 10 of 2011 as the start of the forest moratorium policy. The policy was aimed to reduce the rate of deforestation and forest degradation by controlling the extent of concession area. However, the effectiveness of this policy in achieving these goals is still being debated. This study aims to explore the implementation of forest moratorium policy in Papua Province. The exploration was conducted by exploring the effects of the forest moratorium policy on the rate of deforestation and forest degradation in Papua Province through spatial analysis using ArcGIS software, and exploring the factors affecting the implementation of the forest moratorium policy at the provincial level in Papua through descriptive qualitative analysis using Edwards III approach. The results shows that the forest moratorium policy has successfully reduced the extent of the concession area and the average rate of deforestation and forest degradation in Papua Province. However, the decline of the average rate of deforestation and forest degradation was not accompanied by a steady rate during the enactment of the policy, and further analysis show that the concession extent was not directly proportional to the rate of deforestation and forest degradation in the concession area. This study also reveals that the policy implementation at the provincial level was hampered by the communication factor, the resources factor, and the disposition factor. We recommend that, besides limiting the concession area, the government should improve the licensing governance by strengthening the monitoring and evaluation, as well as the mechanism of business-work-plan approval. Also, the central government should improve coordination with the local government to overcome factors hampering the implementation of the moratorium policy.
\end{abstract}

\begin{abstract}
Abstrak: Pada tanggal 20 Mei 2011, pemerintah Republik Indonesia menerbitkan Instruksi Presiden (Inpres) nomor 10 tahun 2011 sebagai awal diberlakukannya kebijakan moratorium hutan. Kebijakan tersebut bertujuan untuk menekan laju deforestasi dan degradasi hutan dengan mengendalikan luasan areal konsesi. Namun, efektivitas kebijakan ini dalam mencapai tujuan tersebut masih menjadi perdebatan. Studi ini bertujuan untuk mengeksplorasi implementasi kebijakan moratorium hutan di Provinsi Papua. Eksplorasi dilakukan dengan menggali dampak kebijakan moratorium hutan terhadap laju deforestasi dan degradasi hutan di Provinsi Papua melalui analisis spasial menggunakan software ArcGIS, dan menggali faktor-faktor yang mempengaruhi implementasi kebijakan moratorium hutan di tingkat provinsi di Papua melalui analisis deskriptif kualitatif dengan menggunakan pendekatan Edwards III. Hasil studi menunjukkan bahwa kebijakan moratorium hutan telah berhasil mengurangi luasan areal konsesi dan laju rata-rata deforestasi dan degradasi hutan di Provinsi Papua. Namun, penurunan rata-rata laju deforestasi dan degradasi hutan tidak dibarengi dengan laju yang stabil selama berlakunya kebijakan tersebut, dan analisis lebih lanjut menunjukkan bahwa luas konsesi tidak berbanding lurus dengan laju deforestasi dan degradasi hutan di areal konsesi. Studi ini juga mengungkapkan bahwa implementasi kebijakan di tingkat provinsi terhambat oleh faktor komunikasi, faktor sumber daya, dan faktor disposisi. Kami merekomendasikan agar disamping membatasi areal perizinan, pemerintah juga harus meningkatkan sistem tata kelola perizinan dengan memperkuat sistem monitoring dan evaluasi, serta mekanisme pengesahan rencana kerja usaha (RKU). Selain itu, pemerintah pusat juga harus meningkatkan koordinasi dengan pemerintah daerah untuk mengatasi faktor-faktor yang menghambat implementasi kebijakan moratorium hutan.
\end{abstract}

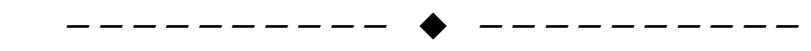

is carbon emissions, in which the most significant contributor to carbon emissions in Indonesia is the forestry sector due to deforestation [1]. Since 1980, 
Indonesia's forest cover has altered significantly, and statistics show declining forest areas over time [2].

Indonesia has a lengthy deforestation history (see Figure 1). Much of it has been triggered by extensive land conversion, legal and illegal logging, economic growth, and forest fires. Between 1970 and 1985, forest logging concessions were one of Indonesia's most influential forest loss drivers [3] . Forest product harvesting, mainly wood, directly drives deforestation in primary natural forests and turns them into secondary/degraded forests [4]. Selective wood harvesting and the advancement of access roads for logging also cause accidental destruction of non-target trees, resulting in unintended deforestation ([5], [6]). Adding to this list, Houghton [7] observed that the development of agricultural land, plantations, fires, and timber harvesting also drives deforestation and forest degradation.



Figure 1. Deforestation (forest cover loss) in Indonesia 2000-2005

Source: World Resources Institute [8]

Several programs have been carried out by the Indonesian government in order to participate in the reduction of climate change. One of them is the forest moratorium policy, which aims to reduce greenhouse gas emissions from deforestation and forest degradation. This policy was carried out through a moratorium on the issuance of new permits and improvements in primary natural forest and peatlands governance. It is expected that by suspending the issuance of new permits, the government can reduce or control the concession area's extent so that the deforestation and forest degradation rate can be reduced.

The Republic of Indonesia government claims that efforts to reduce emissions from deforestation and forest degradation through the forest moratorium policy have successfully reduced deforestation rates. Since the enactment of the forest moratorium policy in 2011, the overall trend of deforestation rates has decreased from 0.61 Mha per year to 0.48 Mha per year in 2017 although the rate is fluctuated as presented in Figure 2.

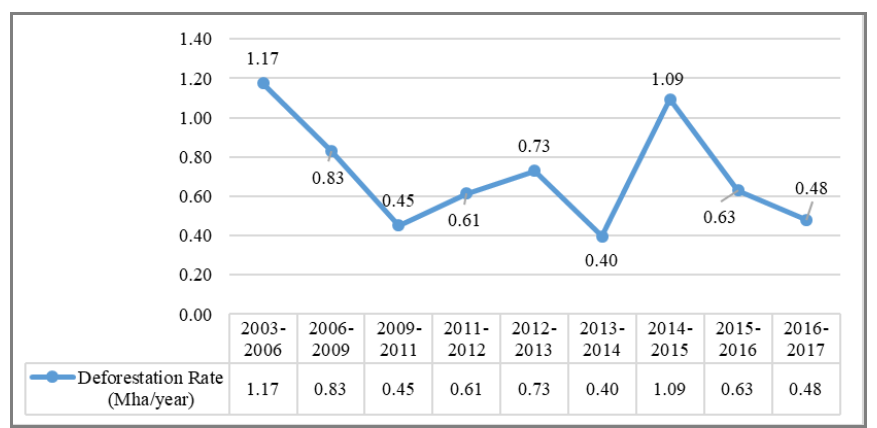

Figure 2. Indonesia's Deforestation Rate

Source: Ministry of Environment and Forestry ([9], [10], [11], [12], [13], [14], [15], [16], and [17])

Although the Government of the Republic of Indonesia claims that the forest moratorium policy has successfully reduced deforestation rates, the effectiveness of this policy in achieving the goals have been debated ([18], [19], [20]). A preliminary review to the deforestation data of Papua Island published by the Ministry of Environment and Forestry shows that unlike the overall trend of the national, the deforestation rates on Papua Island (Papua and Papua Barat Province) during the 2003-2017 period showed an increasing trend. Since the enactment of the forest moratorium policy in 2011, the deforestation rates on the Papua Island have been fluctuated, with an overall increasing trend from 20,300 ha per year to 48,500 ha per year in 2017 (Figure 3).

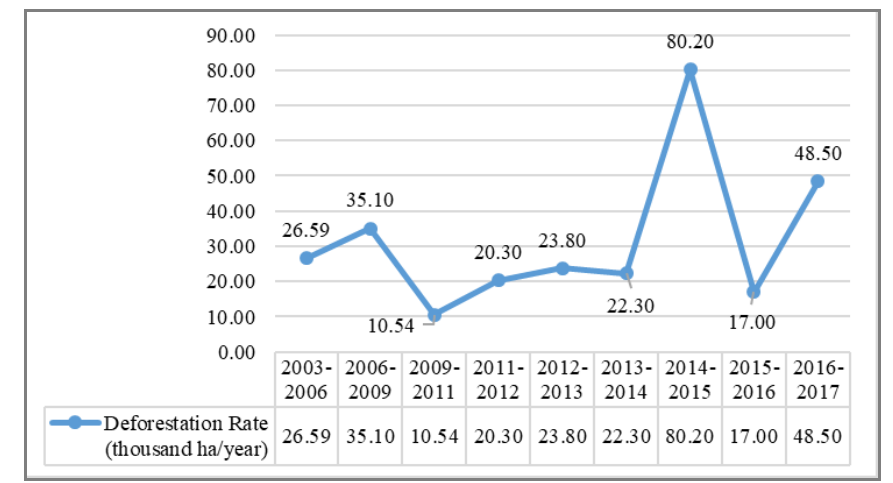

Figure 3. Papua Island's Deforestation Rate

Source: Ministry of Environment and Forestry ([9], [10], [11], [12], [13], [14], [15], [16], and [17])

Ideally, by the enactment of the forest moratorium policy, the deforestation and forest degradation rates should be decreasing. The national deforestation data shows an overall downward trend during the enactment of the policy, but the rates are fluctuating and tend to be unstable. On the other hand, the deforestation data of Papua island, which has the largest forest area in Indonesia, shows an overall increased trend, which is contrary to the objectives of the forest moratorium policy. Therefore, the main objective of this research is to explore the implementation of the forest moratorium policy in Papua Province, which is part of the Papua island. From the main objective, it can be divided into two objectives as follows: 
1. To explore the effects of the forest moratorium policy on the rate of deforestation and forest degradation in Papua Province.

2. To explore the factors affecting the implementation of the forest moratorium policy at the provincial level in Papua.

\section{B. RESEARCH METHOD}

\section{Theoretical Review}

Edwards III [21] defines policy implementation as a dynamic process that involves the interaction of many factors. To be adequately implemented, the preconditions and objectives of the policy must be considered. Policy implementation also defined as a way for a policy to achieve its objectives that can be directly implemented in the context of programs or by indirect policy formulation [22]. Both definitions emphasize the importance of setting clear objectives as guidance in implementing policy.

Forest moratorium policy enacted by the Government of the Republic of Indonesia in 2011 aims to reduce the greenhouse gas emission by reducing deforestation and forest degradation through a moratorium on the issuance of new permits, and through the improvement of primary natural forest and peatlands governance. Deforestation is the permanent alteration of forested areas to non-forested areas, such as arable land, urban usage, logged-over areas, or wasteland, as a result of human activities ([23], [24]). Meanwhile, forest degradation is the deterioration in forest cover density due to increased disruption by human activities resulting in a decline in the function of the forest ([23], [24]).

The primary objectives of the forest moratorium policy is to reduce deforestation and forest degradation. In which the driver of deforestation and forest degradation in Indonesia are illegal logging ([25], [3]), logging concession ([5], [7], [4], [24], [6]; [3], [25]), agricultural land ([7], [23]), plantation ([7], [26], [27]), mining [25], and fire ([7], [25]). From the statement, it shows that, besides illegal logging and fire, deforestation and forest degradation were also significantly drives by the concession.

A concession is a legal instrument used by two entities, commonly the state and a private entity, which grants privileges from the state to the private entity in exchange for payment or service provision [28]. In the context of forest concessions, its involve an agreement between the forest owner and another party allowing forest harvest (forest utilization agreements) and management (forest management services agreements) of designated forest resources in a given forest area, or both [29].

Based on the theories above, concession is one of the significant drivers of deforestation and forest degradation in Indonesia. By analyzing the rate of deforestation and forest degradation based on the concession and non-concession area, the type and the extents of concession areas, the moratorium area, and the forest type, the authors try to explore the effects of the forest moratorium policy on the rate of deforestation and forest degradation in Papua Province.

Policy implementation is the most challenging stage of the entire policy cycle. The contents of the policy and the context of its implementation are crucial factors to consider in this stage. The concept is that the success of a policy depends on the degree of its implementation after the policy is transformed and its implementation is carried out (Grindle, as cited in [30]). This illustrates how important the stages of implementing policy are in achieving the stated objectives. A policy is said to be effective if the outputs of the policy process and the implementing agencies are in line with the policy objectives, using the best available resources ([31], [32]). Edwards III [21] listed four key factors to be simultaneously considered for effective policy implementation: communication, resources, disposition, and bureaucratic structure. Based on those key factors he formulates a theory known as Edward III approach to analyze policy implementation and identify potential obstacles.

The first factor, communication, is the process of delivering information from the communicator to the communicant; in this case, delivering policy information from policymakers to policy implementers/actors. Information needs to be conveyed to policy actors so that they can understand the contents, objectives, directions, and target groups of the policy, prepare any matters related to policy implementation, and run the policy effectively [33]. Three aspects have to be considered in the communication factor are transmission, clarity, and consistency [21].

Clarity and consistency in policy implementation and the accuracy of communication delivery would not be meaningful if the person responsible for implementing the policy lacked the resources to carry out their duty. Four aspects that have to be considered in resources factor are staff, information, authority, and facilities [21].

The third factor influencing effective policy implementation is the disposition or attitude of the implementer. For a policy to be implemented effectively, implementers must not only have the capability and knowledge to carry out the stated objectives but also must have the desire to do so. If the implementer agrees with the policy content and objectives, they will implement it happily. However, if their views differ from that of the policymakers, the resulting implementation process may experience problems. Three aspects must be considered in the disposition factor are the effects of dispositions, staffing the bureaucracy, and incentives [21].

Finally, the implementation of a policy cannot be separated from the actors or the implementers, which 
hence requires the presence of a bureaucratic structure. Bureaucratic structures consist of characteristics, norms, and relationships in executive bodies that have both potential and tangible relationships with what they have in carrying out policies. Policy implementers may know what to do and have sufficient desire and resources to implement a policy, but the implementation may still fail if the existing bureaucratic structure hinders the process. Two aspects that must be considered in the bureaucratic structure are standard operating procedures (SOP) and fragmentation [21].

Based on the theories above, the authors explores the factors affecting the implementation of forest moratorium policy at the provincial level in Papua. By analyzing those factors, the obstacles were explored to formulate recommendation to overcome it.

\section{Research Method}

The research location was Papua Province, which is the largest province in Indonesia with an area covered about $319,036 \mathrm{~km}^{2}$, which is divided into 28 districts and one municipality (Figure 4) [34]. Papua Province is essential to Indonesia's forestry field because more than $90 \%$ of its total land area has been designated as forest area by the government. With the largest forest area in Indonesia, covering about $301,303 \mathrm{~km}^{2}$ area [35], it includes the largest rain forest in Indonesia, which is among the last remaining frontier rain forests in the Asia Pacific region [36]. This forest has one of the highest levels of biodiversity in the world, and is home to 20,000 plant species, 602 bird species, 125 mammal species, and 223 reptile species [37].

A deductive approach using the descriptive qualitative method was employed to achieve the research objective. In this approach, theories and variables become the initial foundation of the research. The policy's implementation was explored by analysis of primary and secondary data collected from related local government officials, agencies, and documents via semistructured in-depth interviews, spatial data analysis, and document review.

The primary data was collected by semi-structured in-depth interviews since it give opportunity to the researcher to "explore" answers, where the researcher wants the interviewees to explain, or build on, their responses [38]. In this context, the interview guide was made based on the variable of Edwards III approach to control the flow of the interview while the researcher explores the answer from the informants to obtain as much information, as completely, and clearly as possible. The selection of informants was carried out by using purposive sampling method to get seven government officials at the provincial level in Papua who represented the Forest Area Consolidation Office Regional X Jayapura, Papua Province Forestry and Environmental Service, Papua Province Regional Development Planning Agency, Papua Province Agriculture and Food Service, Papua Province Regional Office of the National Land
Agency, Papua Province Investment and One-Stop Integrated Services Office, and Papua Province Public Works, Spatial Planning, Housing, and Settlement Areas Service. In this technique, the respondents are deliberately selected by specific considerations to enrich research data [39]. In this study, the selection of informants was carried out based on tracing to the local government officials who were considered to be the most understanding and who most frequently handled processes related to forest moratorium policies.

Meanwhile, the secondary data are in the form of spatial data, related reports, literature, regulations, and other publication sources. The data was obtained from institutions or agencies related to the implementation of forest moratorium policy before then analyzed by spatial and descriptive qualitative analysis and combined with the primary data analysis to enrich the discussion.

Data analysis in this study was conducted using two methods: spatial analysis and descriptive qualitative analysis. The spatial analysis was performed using ArcGIS software to explore the effects of the forest moratorium policy on the rate of deforestation and forest degradation. Land cover spatial data from the Ministry of Environment and Forestry was used to analyze the deforestation and forest degradation rate before and after the enactment of the forest moratorium policy by the overlay method. The provincial spatial data ranged from 2003-2017 divided into nine periods based on land cover data availability consisting of data periods 20032006, 2006-2009, 2009-2011, 2011-2012, 2012-2013, 2013-2014, 2014-2015, 2015-2016, and 2016-2017. The concession area (Utilization of Timber Forest Products in the Natural Forests (IUPHHK-HA), Utilization of Timber Forest Products in the Plantation Forests (IUPHHK-HT), Utilization of Non-Timber Forest Products (IUPHHBK), Forest Area Borrow-Use (IPPKH), Forest Area Release (PKH), and Mining Business Permit (IUP)), and the moratorium area data used in the analysis also followed this periodical classification.

The descriptive qualitative analysis was conducted to analyze the policy implementation at the provincial level in Papua. Primary data obtained from the semistructured in-depth interview analyzed using Edwards III approach to explore the policy implementation and identify potential obstacles based on factors of communication (transmissions, clarity, and consistency), resources (staff, information, authority, and facilities), dispositions (the effect of disposition, staffing the bureaucracy, and incentives), and bureaucratic structure (standard operating procedures (SOP) and fragmentations) [21]. The information obtained from the interview also checked by the triangulation method to informants from the Ministry of Environment and Forestry and the Ministry of Internal Affairs as well as related documents and spatial analysis results to ensure validity. 


\section{RESULTS AND DISCUSSION}

\section{Content of Indonesia's Forest Moratorium Policy}

The forest moratorium policy in Indonesia was established on May 20, 2011 by the enactment of Presidential Instruction (Inpres) No. 10 of 2011, entitled The Moratorium on the Issuance of New Permits and Improvements of Primary Natural Forests and Peatlands Governance. The Presidential Instruction was valid for two years, and was extended by Presidential Instruction No. 6 of 2013, Presidential Instruction No. 8 of 2015, and Presidential Instruction No. 6 of 2017. In 2019, the government decided to make the policy permanent via Presidential Instruction No. 5 of 2019, entitled The Termination on The Issuance of New Permits and Improvement of Natural Primary Forest and Peatlands Governance.

The choice of words in the opening paragraph of the Presidential Instruction "In order to balance and harmonize economic, social, cultural, and environmental development and efforts to reduce greenhouse gas emissions through reducing emissions from deforestation and forest degradation..." implies that the government emphasizes to balance and harmonize economic, social, cultural, and environmental development above the efforts to reduce deforestation and forest degradation. This statement has not been discussed in previous studies, which are more focused on moratorium exemptions as barriers to deforestation reduction. However, it is the author's opinion that the emphasis that the government places on development over deforestation explains why some exemptions exist in the forest moratorium policy, despite being detrimental to its goal of reducing deforestation and forest degradation.

Government agencies related to land resource management and development were included in the forest moratorium policy to help achieve its goals. In the initial three Presidential Instructions, the Ministry of Agriculture, the Ministry of Public Works and Public Housing, and the Ministry of Energy and Mineral Resources were not included in the list, which was criticized by Murdiyarso et al [40]. As an improvement, the Ministry of Agriculture and the Ministry of Public Works were included in the next period, however, the Ministry of Energy and Mineral Resources was not included until the present Presidential Instruction was published. With the increase of licenses in the mining sector as well as the vital role and authority of the Ministry of Energy and Mineral Resources in mining licensing, this exclusion was hampered the policy implementation. Therefore, the Ministry of Energy and Mineral Resources should be included in the list to ensure better implementation.

The forest moratorium policy applies to all permits and concessions on the utilization of primary natural forest areas and peatlands. However, the terms "primary natural forest" and "peatlands" used in the policy represent the loss of opportunities to protect secondary forests and logged-over forests [40], which also suffer from deforestation and forest degradation.

The moratorium policy also listed some activities that were categorized as exemptions. Permits for these activities can still be approved for use in primary natural forests and peatlands. Forest moratorium exemptions can be seen as two sides of a coin. On the one hand, exemptions to applications that have obtained principle permits prior to the enactment of the forest moratorium policy, exemptions to the extension of existing permits, and exemptions to the implementation of a vital national development such as energy supply and food sovereignty programs, can provide space to maintain businesses and investments, and also guarantee ongoing regional and national development. On the other hand, these exemptions may actually hinder the government's efforts to reduce deforestation and forest degradation, particularly when these exemptions allow for parts of primary natural forests and peatlands that are in permits area to become unprotected. The government must establish a stringent, regular monitoring and evaluation program that is accompanied by clear sanctions, when necessary, to ensure that the exemptions provided are on target and not misused by certain parties.

Following the presidential instruction, the government of the Republic of Indonesia, in this context the Ministry of Environment and Forestry (formerly Ministry of Forestry), issuing ministerial decrees that establish the indicative moratorium map. The indicative moratorium map plays a vital role in the policy implementation, since it serves as a reference for government agencies in carrying out duties related to forest moratorium policy.

The indicative moratorium map is updated, revised, and established every six months, and is open for input, complaints, and improvements from the community and other interested parties via a predetermined procedure. This implies that it can function as public scrutiny and allows community members to contribute to its improvement [40]. These updates and revisions can also make difficulties in the implementation and evaluation due to the changes in the moratorium area border. It may also hamper other activities, such as the land registration process [41]. Communication is, therefore, vital to solve this problem and making the policy successful. The central government needs to create methods for excellent communication in order to guarantee policy implementation, as well as the monitoring and evaluation can be carried out properly with the latest data.

\section{Deforestation and Forest Degradation in Papua Province}

Forest moratorium policy aims to reduce greenhouse gas emissions through reducing emissions from deforestation and forest degradation by placing a 
moratorium on the issuance of new permits on the primary natural forest and peatlands area. This policy intended to protect the primary natural forest and peatlands area from being converted to other use. It is expected to reduce the number and extent of permits that have the potential for deforestation and forest degradation activities. The goal is that by decreasing concession area, deforestation and forest degradation will also decrease.

The analysis shows that the average deforestation and forest degradation rate after the enactment of forest moratorium policy in 2011 was far lower than the average before the enactment of the policy. After 2011, the average deforestation rate decreased by about half. The average forest degradation rate after 2011 also decrease to about one-fifth of the average before the enactment of the moratorium policy. (see Table 6)

Analysis of deforestation shows that the deforestation driver changed after the enactment of the forest moratorium policy in 2011. Deforestation pre-2011 was dominated by non-concession areas, which covered 307,514 ha in 2003-2011 compared 83,433 ha in concession areas. The overall average deforestation rate during this period was 48,868 ha per year. Deforestation in the non-concession area, which contributed $79 \%$ to the total deforestation during 2003-2011, can be interpreted as forest encroachment or illegal deforestation activities caused by poor forest governance. The decrease in deforestation rate and the change of the deforestation proportion to the concession areas indicated the success of the forest moratorium policy in reducing deforestation and improving forest governance. Overall, after the enactment of the forest moratorium policy, the deforestation rate was decreased from 23,230 ha per year to 19,252 ha per year with an average of 24,924 ha per year. If the fire incidents excluded, it decreased to 14,605 ha per year with an average of 18,884 ha per year. (see Table 1 and Figure 4)

Table 1. Deforestation rate by concession and nonconcession area

\begin{tabular}{|c|c|c|c|}
\hline \multirow[b]{2}{*}{ Periods } & \multicolumn{2}{|c|}{ Deforestation (ha/year) } & \multirow{2}{*}{$\begin{array}{c}\text { Total } \\
\text { (ha/year) }\end{array}$} \\
\hline & $\begin{array}{c}\text { inside the } \\
\text { concession area }\end{array}$ & $\begin{array}{c}\text { outside the } \\
\text { concession area }\end{array}$ & \\
\hline $2003-2006$ & 15,317 & 69,895 & 85,212 \\
\hline 2006-2009 & 8,424 & 26,770 & 35,195 \\
\hline 2009-2011 & 6,104 & 8,760 & 14,864 \\
\hline 2011-2012 & 12,411 & 10,819 & 23,230 \\
\hline 2012-2013 & 10,942 & 2,229 & 13,171 \\
\hline $2013-2014$ & 10,486 & 9,815 & 20,301 \\
\hline \multirow{2}{*}{ 2014-2015 } & 28,754 & 9,117 & 37,871 \\
\hline & 3,888 & 25,171 & 29,058 \\
\hline \multirow{2}{*}{$2015^{-2016}$} & 2,585 & 1,543 & 4,127 \\
\hline & 1,881 & 653 & 2,534 \\
\hline \multirow{2}{*}{ 2016-2017 } & 10,150 & 4,455 & 14,605 \\
\hline & 4,419 & 228 & 4,647 \\
\hline
\end{tabular}

Note: : fire incident

Source: Author's analysis, 2020

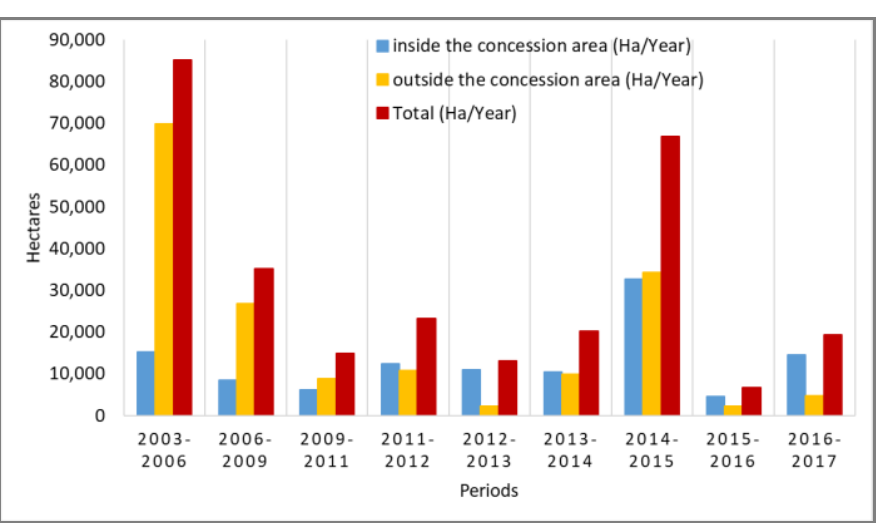

Figure 4. Deforestation rate by concession and nonconcession area

Source: Author's analysis, 2020

The domination of deforestation shifted to the concession area after the enactment of forest moratorium policy. From 2011 to $2017,66 \%$ of all deforestation (excluding fire incidents) took place in the concession areas. Concession area deforestation covered 75,327 ha during this period, as compared to 37,978 ha in non-concession areas. The fire incidents in 2015 and 2016 had a significant impact on deforestation, especially the fire incident in 2015, which was affected by extreme weather due to El Niño. In total, the fire incident contributes 36,239 ha to deforestation in 2015 and 2016, with 26,052 ha in non-concession areas, and 10,187 ha in concession areas (see Table 1). As stated by Glauber et al [42], the forest fires incident in Indonesia in 2015 was indicated to be caused by land clearing activities for agriculture and plantations by burning methods, which were then uncontrolled due to exacerbated by the El Niño phenomenon that created a long period of drought throughout the country.

Table 2. Forest Degradation by concession and nonconcession area

\begin{tabular}{|c|c|c|c|}
\hline \multirow[b]{2}{*}{ Periods } & \multicolumn{2}{|c|}{ Forest Degradation (ha/year) } & \multirow{2}{*}{$\begin{array}{c}\text { Total } \\
\text { (ha/year) }\end{array}$} \\
\hline & $\begin{array}{c}\text { inside the } \\
\text { concession area }\end{array}$ & $\begin{array}{c}\text { outside the } \\
\text { concession area }\end{array}$ & \\
\hline $2003-2006$ & 86,684 & 96,578 & 183,262 \\
\hline 2006-2009 & 168,175 & 120,421 & 288,596 \\
\hline 2009-2011 & 16,682 & 8,410 & 25,092 \\
\hline 2011-2012 & 2,368 & 3,196 & 5,564 \\
\hline 2012-2013 & 5,548 & 7,667 & 13,215 \\
\hline $2013-2014$ & 20,815 & 20,024 & 40,839 \\
\hline \multirow{2}{*}{ 2014-2015 } & 24,873 & 5,426 & 30,299 \\
\hline & $\mathrm{O}$ & $\mathrm{O}$ & $\mathrm{O}$ \\
\hline \multirow{2}{*}{$2015^{-2016}$} & 43,625 & 51,120 & 94,745 \\
\hline & $\mathrm{O}$ & 329 & 329 \\
\hline \multirow{2}{*}{ 2016-2017 } & 9,861 & 4,917 & 14,778 \\
\hline & 222 & 12 & 234 \\
\hline
\end{tabular}

Note: : fire incident

Source: Author's analysis, 2020 


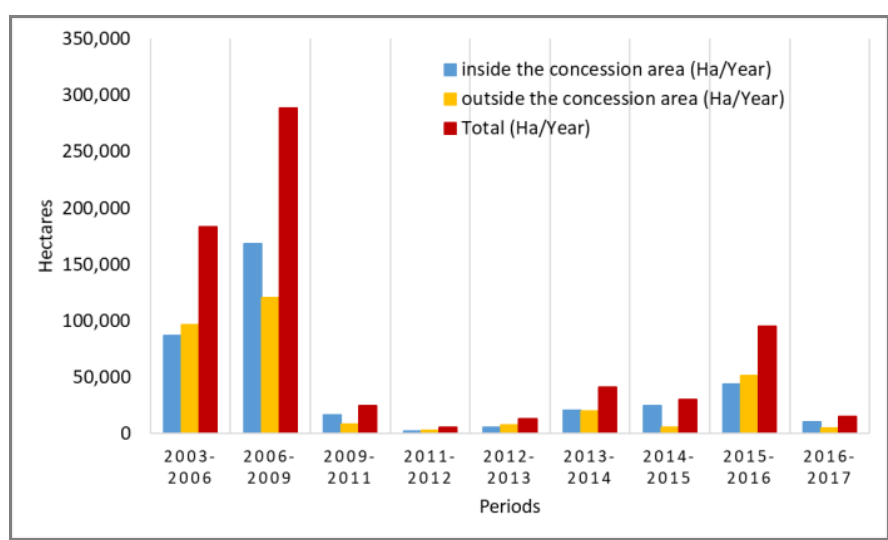

Figure 5. Forest Degradation by concession and nonconcession area

Source: Author's analysis, 2020

Differently with deforestation, forest degradation before and after the enactment of forest moratorium policy was mostly contributed by the concession area. Fifty-four percent of forest degradation occurred in concession areas both before and after the enactment of the forest moratorium policy. Pre-enactment forest degradation covered 797,944 ha in concession areas and 667,814 ha in non-concession areas. After the enactment, forest degradation covered 107,312 ha in concession areas and 92,691 ha in non-concession area.

The average forest degradation rate after the enactment of the moratorium policy decreased substantially. From 2003 to 2011, the average forest degradation rate in the concession area was 99,743 ha per year, compared to 17,885 ha per year (or 17,848 ha/year by excluding the fire incidents) from 2011 to 2017. However, the rate of forest degradation during this period fluctuated, with an increase from 5,564 ha per year to 15,012 ha per year, or to 14,778 ha per year excluding the fire incidents. (see Table 2 and Figure 5)

Table 3. Extents of concession area by type

\begin{tabular}{|c|c|c|c|c|c|c|c|}
\hline \multirow[b]{2}{*}{ Year } & \multicolumn{6}{|c|}{ Extents of Concession Area (ha) } & \multirow[b]{2}{*}{$\begin{array}{c}\text { Total } \\
\text { (ha) }\end{array}$} \\
\hline & $\begin{array}{c}\text { IUPH } \\
\text { HK- } \\
\text { HA }\end{array}$ & $\begin{array}{c}\text { IUPH } \\
\text { HK- } \\
\text { HT }\end{array}$ & $\begin{array}{c}\text { IUPH } \\
\text { HBK }\end{array}$ & $\begin{array}{l}\text { IPP } \\
\text { KH }\end{array}$ & PKH & IUP & \\
\hline $\begin{array}{l}2003- \\
2006\end{array}$ & $\begin{array}{r}7,036 \\
877 \\
\end{array}$ & $\begin{array}{c}192, \\
295\end{array}$ & 0 & $\mathrm{O}$ & $\begin{array}{r}200 \\
763 \\
\end{array}$ & 9,995 & $\begin{array}{r}7,439 \\
930\end{array}$ \\
\hline $\begin{array}{c}2006- \\
2009\end{array}$ & $\begin{array}{r}6,907 \\
243 \\
\end{array}$ & $\begin{array}{l}359, \\
040\end{array}$ & 0 & 150 & $\begin{array}{c}209 \\
896 \\
\end{array}$ & $\begin{array}{r}195,4 \\
49 \\
\end{array}$ & $\begin{array}{r}7,671 \\
779 \\
\end{array}$ \\
\hline $\begin{array}{c}2009- \\
2011\end{array}$ & $\begin{array}{r}6,192 \\
725 \\
\end{array}$ & $\begin{array}{l}359, \\
040\end{array}$ & 0 & 150 & $\begin{array}{r}317,9 \\
96\end{array}$ & $\begin{array}{r}1,406 \\
254 \\
\end{array}$ & $\begin{array}{r}8,276 \\
166 \\
\end{array}$ \\
\hline $\begin{array}{l}2011- \\
2012\end{array}$ & $\begin{array}{r}5,847 \\
072 \\
\end{array}$ & $\begin{array}{r}423 \\
473 \\
\end{array}$ & $\begin{array}{r}58,7 \\
17 \\
\end{array}$ & 150 & $\begin{array}{r}332 \\
463 \\
\end{array}$ & $\begin{array}{r}1,911 \\
075 \\
\end{array}$ & $\begin{array}{r}8,572 \\
950\end{array}$ \\
\hline $\begin{array}{c}2012- \\
2013 \\
\end{array}$ & $\begin{array}{r}5,698 \\
884 \\
\end{array}$ & $\begin{array}{r}423 \\
473 \\
\end{array}$ & $\begin{array}{r}58,6 \\
98 \\
\end{array}$ & 150 & $\begin{array}{r}704 \\
222 \\
\end{array}$ & $\begin{array}{r}2,057 \\
618 \\
\end{array}$ & $\begin{array}{r}8,943 \\
045 \\
\end{array}$ \\
\hline $\begin{array}{l}2013^{-} \\
2014\end{array}$ & $\begin{array}{r}4,952 \\
330\end{array}$ & $\begin{array}{r}423 \\
473\end{array}$ & $\begin{array}{r}383 \\
444\end{array}$ & 192 & $\begin{array}{r}741,7 \\
22\end{array}$ & $\begin{array}{r}2,237 \\
216\end{array}$ & $\begin{array}{r}8,738 \\
378\end{array}$ \\
\hline $\begin{array}{c}2014- \\
2015 \\
\end{array}$ & $\begin{array}{r}5,116 \\
689 \\
\end{array}$ & $\begin{array}{r}423 \\
473 \\
\end{array}$ & $\begin{array}{r}376 \\
195 \\
\end{array}$ & 909 & $\begin{array}{r}934 \\
489\end{array}$ & $\begin{array}{r}2,134 \\
446\end{array}$ & $\begin{array}{r}8,986 \\
200\end{array}$ \\
\hline $\begin{array}{l}2015- \\
2016\end{array}$ & $\begin{array}{r}4,799 \\
641\end{array}$ & $\begin{array}{r}616 \\
316\end{array}$ & $\begin{array}{r}376 \\
195\end{array}$ & 1,256 & $\begin{array}{r}934 \\
489\end{array}$ & $\begin{array}{r}2,221 \\
942\end{array}$ & $\begin{array}{r}8,949 \\
839\end{array}$ \\
\hline $\begin{array}{c}2016- \\
2017\end{array}$ & $\begin{array}{r}2,964 \\
551\end{array}$ & $\begin{array}{r}783 \\
773\end{array}$ & $\begin{array}{r}376 \\
195\end{array}$ & 1,260 & $\begin{array}{r}946 \\
744\end{array}$ & $\begin{array}{r}2,473 \\
309\end{array}$ & $\begin{array}{r}7,545 \\
833\end{array}$ \\
\hline
\end{tabular}

Source: Author's analysis, 2020

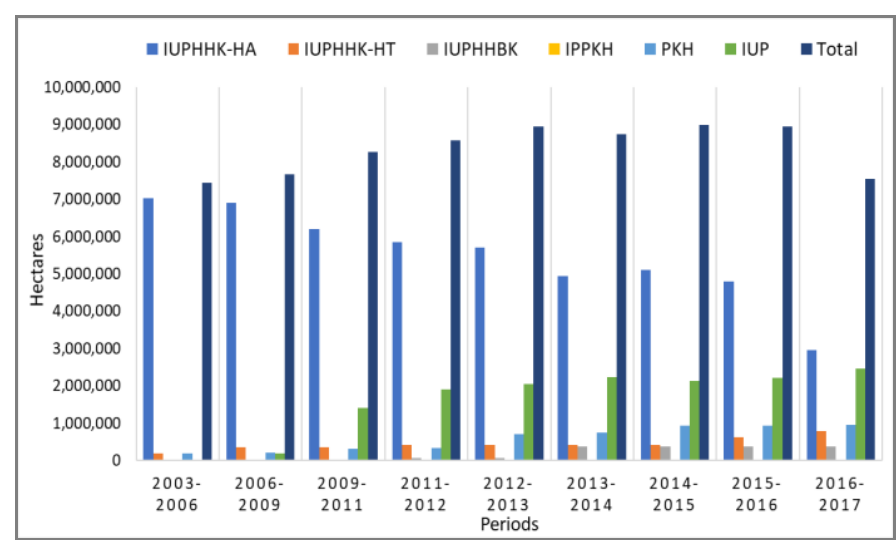

Figure 6. Extents of concession area by type Source: Author's analysis, 2020

The forest moratorium policy could reduce the overall concession area extent. This result is contrary to Jaya et al [19] and Berliani et al [20] arguments, which stated that the moratorium policy could not reduce the number of concessions. However, from six types of concessions analyzed in this research, only IUPHHK-HA was reduced. The extent of IUPHHK-HA was decreased by half during the enactment of forest moratorium policy. It decreased from 5,847,072 ha in the 2011-2012 period to 2,964,551 ha in the 2016-2017 period. (see Table 3 and Figure 6)

The policy succeeded in reducing the extents of IUPHHK-HA, which is one of the most contributed concessions to deforestation and forest degradation. This decreased also followed by the decrease of deforestation rate, which went from 3,034 ha per year to 151 ha per year, with an average of 1,958 ha per year, or 1,894 ha per year when excluding the fire incidents (see Table 4 and Figure 7). However, the decrease of the extents cannot reduce the forest degradation rate, which increased from 1,006 ha per year to 7,589 ha per year, with an average of 8,228 ha per year or 8,227 ha per year when excluding the fire incidents (see Table 5 and Figure 8). It means that the forest degradation rate not only depends on the extents of the concession, but it also depends on the level of the activity of the concession holder. Meaning that the higher the activity, the higher the forest degradation occurred. Despite all, the average deforestation rate in IUPHHK-HA after the enactment of the forest moratorium policy fell to more than one-third, and the average forest degradation was even greater by falling to more than one-eleventh of the average before the enactment of the forest moratorium policy.

The government, in this context, the Ministry of Environment and Forestry, which has the authority to regulate permits for IUPHHK-HA, must be more stringent in regulating the business-work-plan of this type of concession holder. The government should consider the approval of business-work-plans to concession holders by also considering the rate of reforestation so that forest degradation and existing forest area can be maintained. 
Table 4. Deforestation rate by concession type

\begin{tabular}{|c|c|c|c|c|c|c|c|}
\hline \multirow[b]{2}{*}{ Periods } & \multicolumn{6}{|c|}{$\begin{array}{l}\text { Deforestation by type of concession area } \\
\text { (ha/year) }\end{array}$} & \multirow{2}{*}{$\begin{array}{c}\text { Total } \\
\text { (ha/ } \\
\text { year) }\end{array}$} \\
\hline & $\begin{array}{c}\text { IUPH } \\
\text { HK- } \\
\text { HA } \\
\end{array}$ & $\begin{array}{c}\text { IUPH } \\
\text { HK- } \\
\text { HT } \\
\end{array}$ & $\begin{array}{c}\text { IUPH } \\
\text { HBK }\end{array}$ & $\begin{array}{l}\text { IPP } \\
\mathrm{KH}\end{array}$ & PKH & IUP & \\
\hline $\begin{array}{l}2003^{-} \\
2006\end{array}$ & 11,940 & O & O & O & 3,377 & 0 & 15,317 \\
\hline $\begin{array}{l}2006- \\
2009\end{array}$ & 5,839 & $\mathrm{O}$ & $\mathrm{O}$ & O & 2,388 & 197 & 8,424 \\
\hline $\begin{array}{c}2009- \\
2011\end{array}$ & 1,432 & O & 0 & o & 51 & 1,121 & 6,104 \\
\hline $\begin{array}{l}2011- \\
2012\end{array}$ & 3,034 & 320 & 0 & o & 32 & 3,475 & 12,411 \\
\hline $\begin{array}{c}2012- \\
2013 \\
\end{array}$ & 1,143 & 91 & 0 & o & 7,884 & 1,823 & 10,942 \\
\hline $\begin{array}{l}2013^{-} \\
2014\end{array}$ & 2,919 & 0 & 64 & o & 74 & 1,029 & 10,486 \\
\hline \multirow{2}{*}{$\begin{array}{c}2014^{-} \\
2015 \\
\end{array}$} & 4,054 & 834 & 0 & o & 23,86 & 3 & 28,754 \\
\hline & 304 & 416 & 0 & o & 3,160 & 8 & 3,888 \\
\hline \multirow{2}{*}{$\begin{array}{l}2015^{-} \\
2016\end{array}$} & 61 & 0 & 0 & o & 1,953 & 571 & 2,585 \\
\hline & 81 & 0 & 0 & 0 & 1,800 & 0 & 1,881 \\
\hline \multirow{2}{*}{$\begin{array}{l}2016- \\
2017\end{array}$} & 151 & 0 & 0 & $\mathrm{O}$ & 9,964 & 35 & 10,150 \\
\hline & 0 & 0 & 0 & o & 4,391 & 28 & 4,419 \\
\hline
\end{tabular}

Note:

Source: Author's analysis, 2020



Figure 7. Deforestation rate by concession type Source: Author's analysis, 2020

As previously mentioned, the extents of five other concession areas analyzed in this research was increased. They included, in order: PKH, IUP, IUPHHK-HT, IUPHHBK, and IPPKH. The increase of the PKH extents followed by the increase in the deforestation and forest degradation rate in the area. The deforestation rate in PKH increased from 5,582 ha per year in 2011-2012 to 14,355 ha per year in 2016-2017, or to 9,964 ha per year when excluding the fire incidents (see Table 4 and Figure 7). The forest degradation in $\mathrm{PKH}$ also increased from 1,362 ha per year in 2011-2012 to 2,479 ha per year in 2016-2017, or 2,262 ha per year when excluding the fire incidents (see Table 5 and Figure 8). Overall, compared to the period before the enactment of forest moratorium in 2003-2011, the average deforestation and forest degradation rate in the PKH was increased. The average deforestation rate increased more than tripled, and the average forest degradation rate was increased by about one third (see Table 6). This analysis shows that the forest moratorium policy does not affect the extents of the $\mathrm{PKH}$, and also the deforestation and forest degradation rates within these areas.

Table 5. Forest degradation rate by concession type

\begin{tabular}{|c|c|c|c|c|c|c|c|}
\hline \multirow[b]{2}{*}{ Periods } & \multicolumn{6}{|c|}{$\begin{array}{c}\text { Deforestation by type of concession area } \\
\text { (ha/year) }\end{array}$} & \multirow{2}{*}{$\begin{array}{l}\text { Total } \\
\text { (ha/ } \\
\text { year) }\end{array}$} \\
\hline & $\begin{array}{c}\text { IUPH } \\
\text { HK- } \\
\text { HA }\end{array}$ & $\begin{array}{c}\text { IUPH } \\
\text { HK- } \\
\text { HT }\end{array}$ & $\begin{array}{l}\text { IUPH } \\
\text { HBK }\end{array}$ & $\begin{array}{l}\text { IPP } \\
\mathrm{KH}\end{array}$ & PKH & IUP & \\
\hline $\begin{array}{l}2003^{-} \\
2006\end{array}$ & 82,406 & o & o & o & 4,279 & o & 86,684 \\
\hline $\begin{array}{c}2006- \\
2009\end{array}$ & 164,455 & 2,440 & o & o & 157 & 1,124 & 168,175 \\
\hline $\begin{array}{c}2009- \\
2011\end{array}$ & 13,612 & o & o & o & 423 & 2,648 & 16,682 \\
\hline $\begin{array}{l}2011^{-} \\
2012\end{array}$ & 1,006 & 0 & o & o & 1,362 & o & 2,368 \\
\hline $\begin{array}{c}2012- \\
2013\end{array}$ & 2,897 & o & o & o & 2,501 & 150 & 5,548 \\
\hline $\begin{array}{l}2013^{-} \\
2014\end{array}$ & 18,127 & o & 0 & o & 2,641 & 47 & 20,815 \\
\hline \multirow{2}{*}{$\begin{array}{c}2014^{-} \\
2015\end{array}$} & 17,744 & 1,123 & 0 & $\mathrm{O}$ & 3,855 & 2,151 & 24,873 \\
\hline & 0 & 0 & 0 & O & 0 & 0 & $\mathrm{O}$ \\
\hline \multirow{2}{*}{$\begin{array}{l}2015^{-} \\
2016\end{array}$} & 2,005 & $\mathrm{O}$ & 230 & $\mathrm{O}$ & 1,361 & 40,028 & 43,625 \\
\hline & o & o & o & O & o & o & O \\
\hline \multirow{2}{*}{$\begin{array}{c}2016- \\
2017\end{array}$} & 7,584 & 1 & 0 & $\mathrm{O}$ & 2,262 & 15 & 9,861 \\
\hline & 5 & 0 & 0 & $\mathrm{O}$ & 218 & 0 & 222 \\
\hline
\end{tabular}

Note: : fire incident

Source: Author's analysis, 2020

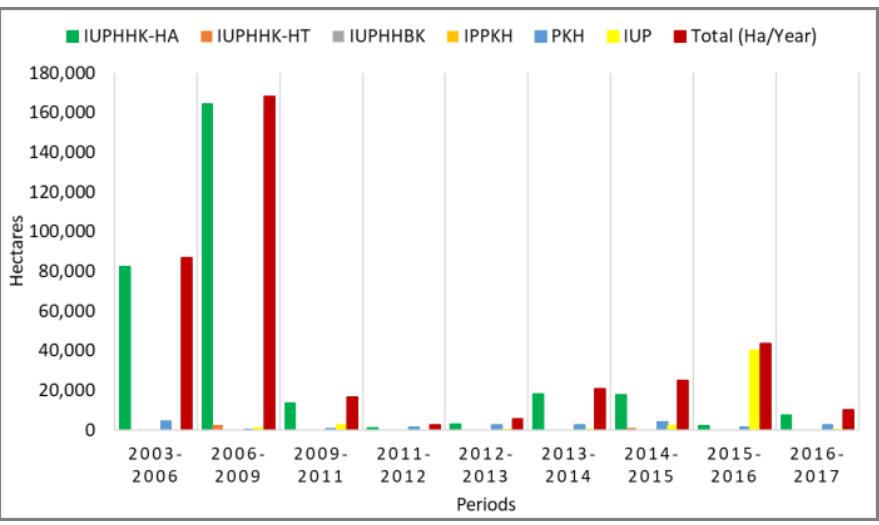

Figure 8. Forest Degradation by concession type Source: Author's analysis, 2020

The extents of PKH issued after the enactment of forest moratorium policy exceeded those issued before 2011. The new PKH permits issued can be categorized as exemptions, since they received their principle permits before the policy's enactment, and since some parts are included in the primary natural forests. Moreover, PKH is actually more than a permit or concession because it changes the allotment of forest areas to non-forest areas intended for activities outside the forestry sector, such as plantations, agriculture, and other development activities. Therefore, there is a high risk that all areas released in the PKH process will eventually be deforested for other uses. 

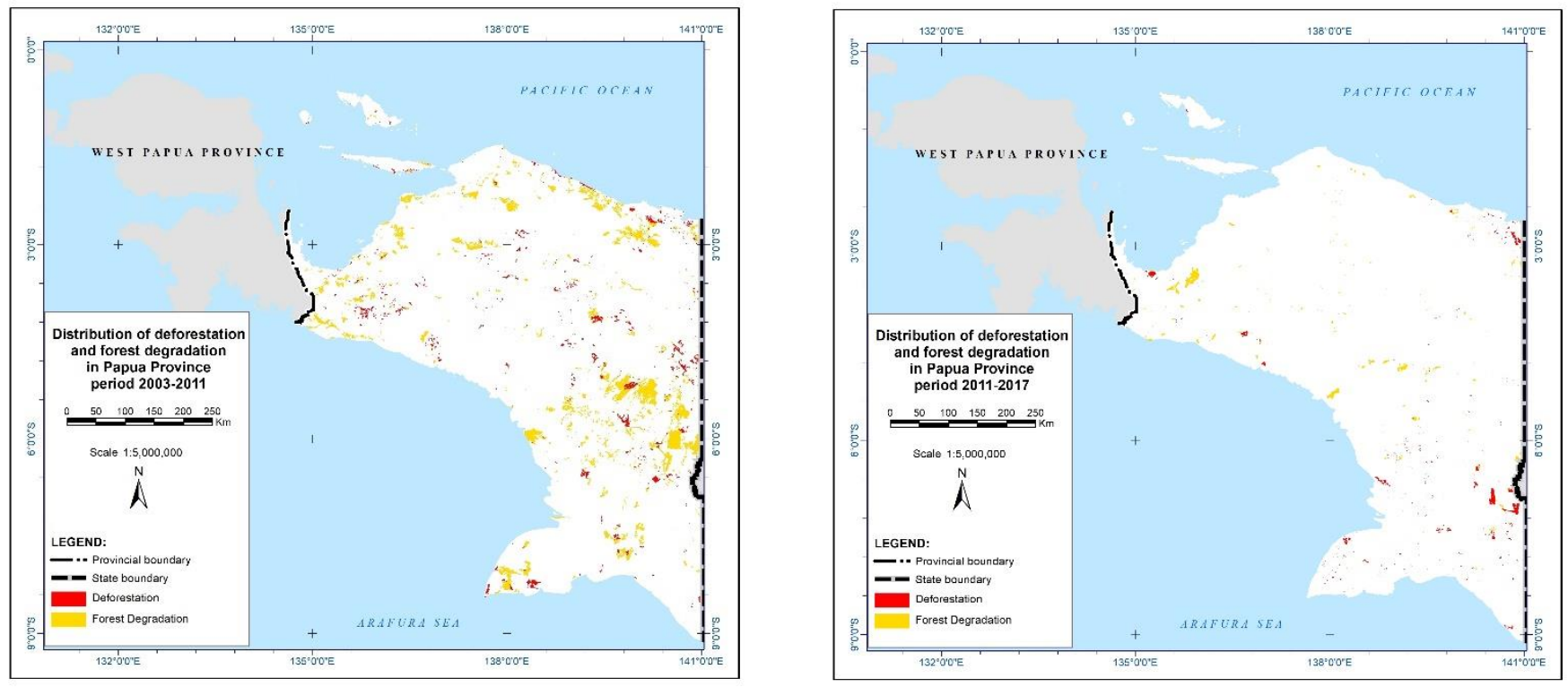

Figure 9. Distribution of Deforestation and Forest Degradation in Papua Province before and after the enactment of forest moratorium policy

Source: Author's analysis, 2020

In the process, after the PKH completed in the Ministry of Environment and Forestry, the released area needs to get activity permit approval from other ministry or agencies, such as the Ministry of Agrarian and Spatial Planning/National Land Agency, the governor, the regent/mayor, or other local governments before any activities can take place. Relevant data from the Ministry of Agrarian and Spatial Planning/National Land Agency and local governments were not able to be obtained for this study, therefore, this analysis only used forest area release (PKH) data issued by the Ministry of Environment and Forestry, under the assumption that permits issued by the relevant institutions will be in the area of PKH issued by the Ministry of Environment and Forestry.

IUP also increased substantially by about 562,235 ha during the 2011-2017 period. The deforestation rate in the IUP areas decreased from 3,475 ha per year in 20112012 to 63 ha per year in 2016-2017, or 35 ha per year when excluding the fire incidents (see Table 4 and Figure 7). Forest degradation rates increased from 0 in 20112012 to 15 ha per year in 2016-2017 (see Table 5 and Figure 8), however, the value of deforestation and forest degradation in 2016-2017 did not represent the rates during the enactment of forest moratorium policy. The average rate of deforestation in IUP during 2011-2017 was 1,162 ha per year or 1,156 ha per year when excluding the fire incidents, which more than tripled compared to the average before the enactment of the moratorium policy (2003-2011) with 354 ha per year. Moreover, the average rate of forest degradation in IUP also increased more than six times from 1,083 ha per year in the 2003-2011 period to 7,065 ha per year in the 2011-2017 period (see Table 6). The significant increase in the average forest degradation rate was mostly caused by forest degradation in 2015-2016, which covered 40,028 ha. (see Table 3 and Figure 6)
Table 6. Comparison table of the average deforestation and forest degradation rate before and after the enactment of forest moratorium policy

\begin{tabular}{|c|c|c|c|}
\hline & \multicolumn{3}{|c|}{$\begin{array}{c}\text { Average rate of deforestation } \\
\text { and forest degradation }\end{array}$} \\
\hline & \multirow[b]{2}{*}{$\begin{array}{c}\text { Before } \\
\text { (ha/year) }\end{array}$} & \multicolumn{2}{|c|}{ After (ha/year) } \\
\hline & & $\begin{array}{c}\text { include } \\
\text { fire } \\
\text { incident }\end{array}$ & $\begin{array}{l}\text { exclude } \\
\text { fire } \\
\text { incident }\end{array}$ \\
\hline Deforestation & 48,868 & 24,924 & 18,884 \\
\hline Concession area & 10,429 & 14,252 & 12,555 \\
\hline IUPHHK-HA & 7,025 & 1,958 & 1,894 \\
\hline IUPHHK-HT & o & 277 & 208 \\
\hline IUPHНBK & o & 11 & 11 \\
\hline IPPKH & o & o & o \\
\hline $\mathrm{PKH}$ & 3,050 & 10,845 & 9,287 \\
\hline IUP & 354 & 1,162 & 1,156 \\
\hline $\begin{array}{l}\text { Non-concession } \\
\text { area }\end{array}$ & 38,439 & 10,672 & 6,330 \\
\hline Forest Degradation & 183,220 & 33,334 & 33,240 \\
\hline Concession area & 99,743 & 17,885 & 17,848 \\
\hline IUPHHK-HA & 95,976 & 8,228 & 8,227 \\
\hline IUPHHK-HT & 915 & 187 & 187 \\
\hline IUPHНВК & o & 38 & 38 \\
\hline IPPKH & o & o & o \\
\hline $\mathrm{PKH}$ & 1,769 & 2,367 & 2,330 \\
\hline IUP & 1,083 & 7,065 & 7,065 \\
\hline $\begin{array}{l}\text { Non-concession } \\
\text { area }\end{array}$ & 83,477 & 15,448 & 15,392 \\
\hline
\end{tabular}

Note:

Before the enactment of forest moratorium policy: 2003-2011 period

After the enactment of forest moratorium policy: 2011-2017 period

Source: Author's analysis, 2020 
The increase of the average deforestation and forest degradation rate in IUP areas after the enactment of the forest moratorium policy shows that IUP deserves more attention in the implementation of the forest moratorium policy. IUPs are under the authority of the Ministry of Energy and Mineral Resources, as well as the local government. The fact that the Ministry of Energy and Mineral Resources was not listed in the Presidential Instruction and most of the permits issued after the enactment of forest moratorium policy were issued by the governor and regent need to be considered.

Further analysis of IUPs issued after the enactment of the forest moratorium policy also shows that the majority of IUPs issued during this period overlapped with the moratorium areas (Figure 10). This condition shows the importance of involving the Ministry of Energy and Mineral Resources, as it has authority in the mining sector. Moreover, it also shows the urgent need for the monitoring and evaluation of policy implementation at the local government level. Monitoring and evaluation activities need to be carried out regularly to ensure the correct implementation of policies, and if necessary, strict sanctions can be made against any violations that occur, in order to ensure the achievement of policy objectives.

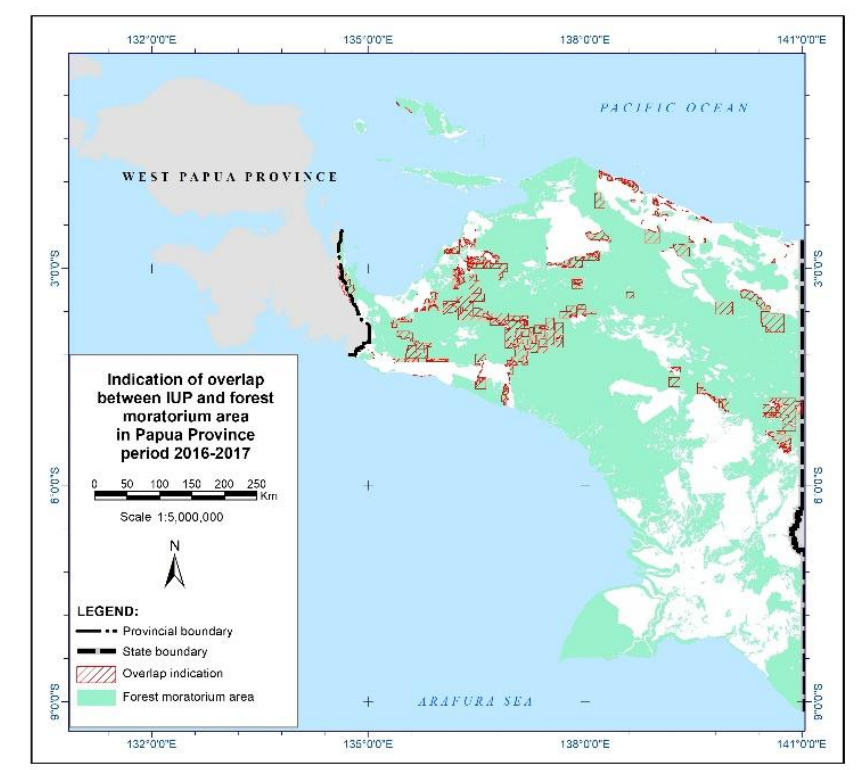

Figure 10. Example of overlap indication between IUP and forest moratorium area in the period of 2016-2017 Source: Author's analysis, 2020

IUPHHK-HT became the third most concession extents increase after the enactment of forest moratorium policy. The extents increase from 423,473 ha to 783,773 ha during the 2011-2017 period, in which 112,561 ha came from moratorium exemptions (see Table 3 and Figure 6). This increase followed by the deforestation rate, which had an average of 277 ha per year during 2011-2017, or 208 ha per year when excluding the fire incidents, compared to a rate of zero deforestation in the 2003-2011 period. The increase of concession extents did not increase the forest degradation rate in the area, in which the average forest degradation rate was decreased from 915 ha per year in the 2003-2011 period to 187 ha per year in the 2011-2017 period (see Table 6).

This analysis shows that the deforestation and forest degradation rate in IUPHHK-HT areas not only depends on the extents of the concession but also the level of activities of the concession holder. It means that the Ministry of Environment and Forestry has to be more careful when issuing business-work-plan approvals. Furthermore, IUPHHK-HT are usually given in forest areas that are not productive to be developed into plantation forests. In principle, if it well implemented, the issuance of new permits will not significantly impact deforestation or forest degradation.

The next concession that increased in the extents after the enactment of forest moratorium policy was IUPHHBK, which increased by about 317,478 ha during the 2011-2017 period (see Table 3 and Figure 6). This increase did not have a significant effect on deforestation or forest degradation. The concession only contributed to deforestation in the 2013-2014 period by 64 ha (see Table 4 and Figure 7), and to forest degradation in 20152016 by 230 ha (see Table 5 and Figure 8), which is very insignificant compared to the overall deforestation and forest degradation rates in the concession areas. However, it was still an increase, because this type of concession did not contribute to deforestation and forest degradation during 2003-2011.

All of the IUPHHBK concessions issued during 2003-2017 in Papua Province were issued by the regent. The permits were classified as moratorium exemptions since it categorized as food sufficiency programs. The type of non-timber product intended in this permit was sago, which is a food staple for the people of Papua. Even though it was categorized as a moratorium exemption, its implementation required strict monitoring to avoid abuse, since, based on this analysis, more than half of the approved permits were given in primary natural forests area.

Concession that least increased in extents during the enactment of the forest moratorium policy was IPPKH. This concession increased 1,110 ha from 150 ha to 1,260 ha during the 2011-2017 period (see Table 3), without contributing to deforestation or forest degradation. All of IPPKH concessions issued after the enactment of the forest moratorium policy can be categorized as moratorium exemptions, as the activities were related to electricity, energy supply, or the development of public infrastructure facilities (e.g., roads). As with IUPHHBK concessions, IPPKH also requires strict monitoring in its implementation to ensure that there is no misuse of permits.

As additional, the deforestation and forest degradation based on the moratorium area and the forest type also analyzed. The results show that the deforestation and forest degradation are still happening in the moratorium area. Meaning that the moratorium 
area cannot fully prevent the forest from encroachment. Another analysis also shows that the secondary forest which is not covered by the moratorium policy became the significant contributor to the deforestation rate which should be concerned by the government.

\section{Implementation of Forest Moratorium Policy at the Provincial Level in Papua}

Policy implementation is one of the most critical stages in the policy cycle. This process involves the interaction of numerous factors [21], and in several circumstances, it also involves organizations without hierarchical links [43] for achieving the objectives. Forest moratorium policy is based on Presidential Instructions and implemented by the related government agencies in the central and local governments. As the decision is made by the central government, it can be classified as a top-down policy [44].

Considering the interaction of several factors and agencies involved, this section aims to explore the implementation of forest moratorium policy at the provincial level in Papua. Using the Edwards III approach, the analysis attempts to explore the factors that affect the implementation of the policy by the implementer at the provincial level, wherein an effective policy implementation has to simultaneously consider four factors, namely communication, resources, disposition, and bureaucratic structure [21].

The implementation of forest moratorium policy involves the central and local government as the implementer. Among seven agencies at the provincial level in Papua interviewed, two of them were the technical implementation units of the ministries. The Forest Consolidation Office Regional X Jayapura (BPKH) as the technical implementation unit of the Ministry of Environment and Forestry and the Papua Province Regional Office of National Land Agency (Kanwil BPN) as the technical implementation unit of the Ministry of Agrarian and Spatial Planning/National Land Agency.

\section{a. Communication}

There were three aspects that have to be considered in the communication factor, such as transmission, clarity, and consistency [21]. The transmission becomes an aspect that has to be considered as a barrier in the policy implementation by the central government as the policymaker. The clarity and consistency have not become a barrier in this case since the directives, data, and information concerning the implementation of the policy is directly based and clearly stated on the Presidential Instruction and ministerial decree. The issues highlighted in the transmission aspect are the absence of direct dissemination and the transmission time of the data and information to the local government.

All informants in Papua Province complain about the absence of direct dissemination of the forest moratorium policy from the central government. They stated that the direct dissemination specifically held for the policy is important to give more detailed information and broader effect to the implementing agencies in Papua Province. Dissemination through circulars was not as effective as direct dissemination as it was only a one-way information flow without any chance of getting more curiosity toward the policy. Furthermore, information from circulars is generally known to only limited personnel in the agencies, as reflected by the limited number of personnel in the implementing agencies who understood the policy.

Most of the implementing agencies in Papua Province also complained about the transmission time of the data and information related to the new updates or revision of the indicative moratorium map, which is often delayed. This was confirmed by the informants from the Ministry of Environment and Forestry who handled permits related to Papua Province, who stated that the licensing recommendations issued by the governor of Papua had actually referred to an indicative moratorium map, but the data used were often not up to date. There were even two local government agencies stated that they had never obtained such data.

\section{b. Resources}

Four aspects that have to be considered in the resources factor are staff, information, authority, and facilities [21]. Based on the interview, the staff and information are the important aspects that must be considered as an obstacle in the implementation of the forest moratorium policy in Papua Province. The authority and facilities aspects does not become an obstacle since the authority given by the policy to each agency in this context was sufficient, and the facilities used in the implementation have been fulfilled from the facilities available at each agency. The staff aspect becomes an issue since two of five local government agencies mentioned that they lacked competent staff for implementing the moratorium policy, especially the absence of staff with mapping expertise. To date, they had overcome this problem by coordinating with other related agencies having competent staff. However, this method is not effective since they cannot maintain the database and the related staff could not be available at all times. Actually, the lack of competent staff was also faced by other agencies in Papua Province, but they were able to optimize the available competent staff. One of the solutions to this problem is related to the disposition factor. With the supports of the leadership, the lack of staff issues can be solved by staffing the bureaucracy or upgrading the staff competency through training and education programs.

Another aspect that is considered as an obstacle in the resource factor is information. In this context, the information about how to carry out the policy and the information about the data supporting the implementation of the policy was sufficient and did not become an issue. The factor that is an important issue is the availability of data on compliance to the forest 
moratorium policy, wherein it is important to evaluate the effectiveness of policy implementation. Essentially, compliance data can be obtained from the monitoring activities on the implementation of a policy. The urgency of the monitoring activities and the compliance data were also supported by the analysis in the previous section, which showed that some of the permits issued after the enactment of the forest moratorium policy overlapped with the moratorium area. However, all the informants stated that to date there were no monitoring activities on the implementation of the forest moratorium policy at the provincial level and that there has been no guidance or supervision and monitoring related to the implementation of the forest moratorium policy that has been made by the central government, which confirmed Austin et al [45] argument.

The last statement of the abovementioned paragraph was denied by the informant from the Ministry of Internal Affairs. The informant stated that in 2013 the ministry had issued a guideline for monitoring and evaluation as well as for reporting the implementation of the forest moratorium policy at the local level. The guideline was disseminated to the regional government through circulars addressed to governors, regents, and mayors throughout Indonesia, where the implementation of reporting was coordinated by the governor and reported to the Minister of Internal Affairs every six months. However, they stated that the response from the regional government, especially from the eastern regions, was indeed lacking. Therefore, it can be assumed that compliance data in Papua Province were not available. The absence of monitoring activities in this context can be caused by several aspects, such as the failure in the transmission of the guideline from the Ministry of Internal Affairs to the local government, the lack of number or competency of the staff resulting in the inability to conduct monitoring activities [21], and the lack of willingness of the implementers to conduct monitoring due to the disagreement on the content or objective of the moratorium policy [21].

\section{c. Disposition}

The effects of disposition, staffing the bureaucracy, and incentives were three aspects that have to be considered in the disposition factor [21]. In this context, the effect of the disposition aspect has to be considered as a barrier in the implementation of the moratorium policy. All the informants were aware of the content of the policy, and they believed that the policy was effective in reducing deforestation and forest degradation as well as could protect and maintain the forested areas and improve the forest and licensing governance in Papua Province. However, all of them felt that Papua Province should have been an exception in the implementation because the majority of area in Papua Province is covered by forest with high potential of natural resources but still far behind other provinces in terms of development and human resource quality. Some of them believed that the concession could help improve the standard of living of people in the hinterlands that have not yet been reached by the government, and the province still requires much space to develop. These opinions imply that there is actually a slight disagreement among agencies at the provincial level, based on which it can be considered that in certain situations, it could lead to rejection in policy implementation or a violation of the provisions in implementing the policy [21]. Furthermore, this also considered as one of the driving factors that cause some permission overlap with the forest moratorium area.

Other aspects of disposition did not become a barrier to the implementation of the forest moratorium policy in Papua Province, where there was no staff arrangement and incentive system specifically related to policy implementation. Although, one of the solutions related to the lack of competent staff in several agencies can be overcome through the process of staffing the bureaucracy or upgrading the staff competency by training activities, with the support of leadership.

\section{d. Bureaucratic Structure}

Policy implementation cannot be separated from actors or implementers, nor can it be separated from the bureaucratic structure. Policy implementers may be aware of what to do and have sufficient desire and resources to implement a policy, but the implementation may still fail if the existing bureaucratic structure hinders the process. Standard operating procedures (SOP) and fragmentation are the two important elements of bureaucracies [21].

Most of the informants stated that there were no specific SOP issued by the central government and the local government related to the implementation of forest moratorium policy. To date, there has never been a problem in the implementation because the information stated in the Presidential Instructions and Ministerial Decree was clear. Furthermore, the implementation of the forest moratorium policy is attached to the main duties of each agency, so that the SOP used are the main duties' SOP by automatically adding the forest moratorium and the indicative moratorium maps as a consideration in the licensing or recommendation review process conducted by each agency.

However, the informants from the Ministry of Internal Affairs, the ministry in charge of local governments, stated that in 2013 the ministry issued a guideline for monitoring and evaluation as well as reporting of Presidential Instruction number 6 of 2013 regarding the moratorium of new permits and improvements of primary natural forests and peatlands governance in the local government. The guidelines were intended to be used for the implementation of the forest moratorium policy at the regional level. Until this point, it is assumed that it might be a problem in the transmission of this guideline from the Ministry of Internal Affairs to the Papua Province local government. 
Fragmentation is the dispersion of policy responsibilities among several organizational units involved in the implementation of policy. This is required because of the involvement of more actors and agencies, the greater interdependence of their decision, the less probability of successful implementation. The division of tasks and responsibilities of agencies in the Presidential Instructions reflects the fragmentation in implementing the forest moratorium policy. In the application at the provincial level, there is also the fragmentation based on the duties and responsibilities of each agency under the coordination of the governor. All the informants mentioned that in the agency's internal implementation, they do not have a special section for handling the implementation of the moratorium policy, because the process is integrated with the regular licensing process.

Regarding the coordination, all informants stated that there was no routine coordination among the implementing agencies in Papua Province. The coordination was done incidentally based on the case of permits or recommendation that needs to be discussed. The form of the coordination also varied, wherein there was direct coordination to the related agency, letter of coordination, and also coordination meetings among the implementing agencies. To date, there have been no issues concerning the coordination since it had been sufficient to deal with issues related to the implementation of the forest moratorium policy.

\section{CONCLUSSIONS AND RECOMMENDATIONS}

Forest moratorium policy enacted by the Government of the Republic of Indonesia in 2011 aimed to reduce the rate of deforestation and forest degradation by controlling the extent of concession area through a moratorium on the issuance of new permits in the primary natural forest and peatlands area. This study shows that the moratorium policy has succeeds in reducing the average deforestation and forest degradation rate compared to the period before the enactment of the policy. However, the decline in the average rate of deforestation and forest degradation has not been followed by a steady rate per year during the enactment of the policy which is fluctuating, and if the rate is compared between the 2016-2017 period and the 2011-2012 period as the start of the moratorium policy, the deforestation trend has decreased slightly, but conversely, the forest degradation trend increased.

The policy has also successfully reduced the overall extents of the concession area, which is contrary to Jaya et al [19] and Berliani et al [20] arguments. However, further exploration shows that the extent of concessions was not directly proportional to the rate of deforestation and forest degradation in the concessions area. The decrease in the extent of concessions after the enactment of the forest moratorium policy turned out to be inversely proportional to the average rate of deforestation in the concessions area, which was increased compared to the period before the enactment of the policy. Conversely, the average rate of forest degradation in the concessions area decreased compared to the period before the enactment of the policy.

The decrease in the overall extent of the concessions area after the enactment of the forest moratorium policy was actually only affected by the IUPHHK-HA permits, while the five other concession types increased. $\mathrm{PKH}$ and IUP were the two concession types with the largest increase in extent. Most of the PKH was classified as exemptions due to the process, which implies that the exemption criteria increase the risk of deforestation and forest degradation since, in this context, they were intended for activities outside the forestry sector. Meanwhile, the IUP should be a concern, because they are under the authority of the Ministry of Energy and Mineral Resources, which was not listed in the Presidential Instruction. Moreover, deforestation and forest degradation that still occurred in the moratorium area should be a concern of the government. The secondary forest that dominated deforestation in the period before and after the enactment of the moratorium policy, in addition to the fire incident, which had a significant effect on the deforestation rate in 2014-2015, should also be a concern.

Analysis of the implementation of the forest moratorium policy at the provincial level in Papua using Edwards III approach shows that the implementation of forest moratorium policy at the provincial level in Papua hampered by the communication factor, resources factor, and disposition factor. The results highlighted the transmission aspect of the communication factor, the staff and information aspects of the resources factor, and the aspect of the effects of disposition of the disposition factor as factors that hampered the success of the policy implementation in Papua Province. These findings complement the findings of Austin et al [45], which mentioned that the policy implementation in districts levels hampered by the poor understanding, monitoring, and enforcing of the moratorium policy by the local government officials, which in Edwards III approach can be classified as resources factor.

The transmission aspect became an issue in the communication factor since there was no direct dissemination of the policy and late transmission of the indicative moratorium map data updates. The absence of direct dissemination was considered as one of the causes of limited staff understanding about the moratorium policy. Meanwhile, the late transmission of the indicative moratorium map data updates reduced the effectiveness of policy implementation by the central and local governments.

The resources factor contributed two issues with regard to the implementation of the moratorium policy in Papua Province. The aspect of staff was a problem since there was a lack of competent staff to implement 
the policy at local government agencies. The information aspect was also a problem because of the unavailability of policy compliance data due to the absence of monitoring activities at the provincial level. The absence of monitoring activities in Papua Province was considered as one of the causes of the indicated violation that occurred in the implementation of the forest moratorium policy.

Another issue in the implementation of the forest moratorium policy in Papua Province arose from the disposition factor, namely the aspect of the effect of the disposition. There were opinions from the informants that implied a slight disagreement from agencies at the provincial level about the forest moratorium policy. Which is, according to [21], in certain situations, this could lead to rejection of implementation or a violation of the provisions in implementing the policy.

The results of this study indicate that the implementation of the forest moratorium policy has not been optimal at reducing the rate of deforestation and forest degradation in Papua Province. However, this policy has had a positive effect, and its implementation must continue. Moreover, with the high reduction of forested areas in Sumatra and Kalimantan, Papua will become the next destination for forest concession holders in Indonesia. Therefore, a mechanism is needed to limit forest exploitation in Papua Province through policies such as forest moratoriums. Based on the study, we recommend that:

1. Besides limiting the concession area, the government should improve the licensing governance by strengthening the monitoring and evaluation, as well as the mechanism of business-work-plan approval.

2. The inclusion of the Ministry of Energy and Mineral Resources in the Presidential Instruction will be essentials for the implementation of forest moratorium policy regarding its authority in Mining Business Permit (IUP).

3. The government should pay more attention to the application of exemption criteria related to concessions because, to date, only IUPHHK-HA that has been limited in extents since the enactment of the forest moratorium policy. In contrast, five other types of permits have increased. Monitoring and evaluation of the licensing process and its extensions must be more stringent, include a measurable mechanism, and be supported by strict enforcement.

4. The Ministry of Environment and Forestry, as the focal point in the forest moratorium policy, should improve coordination among the implementing agencies at the central government level, as well as the local government as the spearhead in the implementation of the policy in regional level. Regular, direct dissemination of information is needed to improve awareness and understanding among the implementing agencies, especially at the local level, as well as acceleration of transmission time of data and information updates related to the moratorium policy.

5. Since most communities in Papua still depend on forested areas for their livelihoods, the actors involved in creating and implementing a forest moratorium policy must come up with a policy that supports the communities around the forest to minimize forest encroachment. This policy could be in the form of a community forest program, providing employment, skills training programs, or other activities to improve the livelihood of the people around the forest in order to reduce the intensity of forest encroachment by the community.

This study empirically explored the implementation of the forest moratorium policy in Papua Province by exploring the effects of the forest moratorium policy on the rate of deforestation and forest degradation and exploring the factors affecting the implementation of the policy at the provincial level. The first one was analyzed using spatial data on periodic land cover, indicative moratorium area, as well as permits of IUPHHK-HA, IUPHHK-HT, IUPHHBK, IPPKH, PKH, and IUP. However, for more detailed analysis, further research is needed to include spatial data on cultivation rights (HGU) from the Ministry of Agrarian and Spatial Planning/National Land Agency, agricultural and plantation permits from the Agriculture and Food Service, and locations of infrastructure construction from the Public Works, Spatial Planning, Housing, and Settlement Areas Service and the Ministry of Public Works and Housing, which could not be obtained by the author.

\section{ACKNOWLEGDMENTS}

The author would like to thank PusbindiklatrenBappenas as the party who has provided the scholarships and financial assistance for this research. The author also would like to thanks all those who have helped in the process until the completion of this research.

\section{REFERENCES}

[1] R. Boer et al., Indonesia Second National Communication Under The United Nations Framework Convention on Climate Change (UNFCCC). Jakarta: Ministry of Environment Republic of Indonesia, 2010.

[2] M. Brockhaus, K. Obidzinski, A. Dermawan, Y. Laumonier, and C. Luttrell, "An overview of forest and land allocation policies in Indonesia: Is the current framework sufficient to meet the needs of REDD+?," For. Policy Econ., vol. 18, pp. 30-37, 2012.

[3] R. Tsujino, T. Yumoto, S. Kitamura, I. Djamaluddin, and D. Darnaedi, "History of forest loss and degradation in Indonesia," Land use policy, vol. 57, pp. 335-347, 2016.

[4] B. A. Margono, P. V. Potapov, S. Turubanova, F. Stolle, and M. C. Hansen, "Primary forest cover loss in indonesia over 2000-2012," Nat. Clim. Chang., vol. 4, no. 8, pp. 730-735, 2014.

[5] R. Burgess and B. A. Olken, "the Political Economy of Deforestation in the Tropics," Q. J. Econ., no. April, pp. 1707-1754, 2012.

[6] J. Indarto, S. Kaneko, and K. Kawata, "Do forest permits 
cause deforestation in Indonesia?," Int. For. Rev., vol. 17, no. 2, pp. 165-181, 2015.

[7] R. A. Houghton, "Carbon emissions and the drivers of deforestation and forest degradation in the tropics," Curr. Opin. Environ. Sustain., vol. 4, no. 6, pp. 597-603, 2012.

[8] W. R. Institute, "Forest Cover Loss in Indonesia , 20002005 / Hilangnya Tutupan Hutan di Indonesia tahun 2000-2005,"WRI Indonesia, 2010. [Online]. Available: https://wri-indonesia.org/id/resources/maps/forestcover-loss-indonesia-2000-2005-hilangnya-tutupanhutan-di-indonesia-tahun-2000. [Accessed: 20-Jul2020].

[9] Departemen Kehutanan, Penghitungan Deforestasi Indonesia Tahun 2008. Jakarta: Pusat Inventarisasi dan Perpetaan Hutan, Badan Planologi Kehutanan, Departemen Kehutanan, 2008.

[10] Kementerian Kehutanan, Penghitungan Deforestasi Indonesia Periode 2006-2009. Jakarta: Direktorat Inventarisasi dan Pemantauan Sumber Daya Hutan, Direktorat Jenderal Planologi Kehutanan, Kementerian Kehutanan, 2011.

[11] Kementerian Kehutanan, Penghitungan Deforestasi Indonesia Periode 2009-2011. Jakarta: Direktorat Inventarisasi dan Pemantauan Sumber Daya Hutan, Direktorat Jenderal Planologi Kehutanan, Kementerian Kehutanan, 2012

[12] Kementerian Kehutanan, Penghitungan Deforestasi Indonesia Periode 2011-2012. Jakarta: Direktorat Inventarisasi dan Pemantauan Sumber Daya Hutan, Direktorat Jenderal Planologi Kehutanan, Kementerian Kehutanan, 2013.

[13] Kementerian Lingkungan Hidup dan Kehutanan, Deforestasi Indonesia Tahun 2012-2013. Jakarta: Direktorat Inventarisasi dan Pemantauan Sumber Daya Hutan, Direktorat Jenderal Planologi Kehutanan, Kementerian Lingkungan Hidup dan Kehutanan, 2014.

[14] Kementerian Lingkungan Hidup dan Kehutanan, Deforestasi Indonesia Tahun 2013-2014. Direktorat Inventarisasi dan Pemantauan Sumber Daya Hutan, Direktorat Jenderal Planologi Kehutanan dan Tata Lingkungan, Kementerian Lingkungan Hidup dan Kehutanan, 2015.

[15] Kementerian Lingkungan Hidup dan Kehutanan, Deforestasi Indonesia Tahun 2014-2015. Jakarta: Direktorat Inventarisasi dan Pemantauan Sumber Daya Hutan, Direktorat Jenderal Planologi Kehutanan dan Tata Lingkungan, Kementerian Lingkungan Hidup dan Kehutanan, 2017.

[16] Kementerian Lingkungan Hidup dan Kehutanan, Deforestasi Indonesia Tahun 2015-2016. Jakarta: Direktorat Inventarisasi dan Pemantauan Sumber Daya Hutan, Direktorat Jenderal Planologi Kehutanan dan Tata Lingkungan, Kementerian Lingkungan Hidup dan Kehutanan, 2017.

[17] Kementerian Lingkungan Hidup dan Kehutanan, Deforestasi Indonesia Tahun 2016-2017. Jakarta: Direktorat Inventarisasi dan Pemantauan Sumber Daya Hutan, Direktorat Jenderal Planologi Kehutanan dan Tata Lingkungan, Kementerian Lingkungan Hidup dan Kehutanan, 2018.

[18] K. Austin, S. Sheppard, and F. Stolle, "Indonesia's Moratorium on New Forest Concessions: Key Findings and Next Steps," World Resour. Inst. Work. Pap., no. February, pp. 1-8, 2012.

[19] I. N. S. Jaya et al., "Analisis Kebijakan Penundaan Pemberian Izin Baru dan Penyempurnaan Tata Kelola Hutan Alam Primer dan Lahan Gambut," Walhi dan Kemitraan. Walhi dan Kemitraan, Jakarta, pp. 1-11, 2014.

[20] H. Berliani, Suwito, J. Waluyo, A. Prameswari, L. M. Syarif, and G. Hardiyanto, "Penguatan Kebijakan Moratoriun Perizinan di Hutan Alam Primer dan Lahan Gambut," Partnersh. Policy Pap. No.8/2016, pp. 1-13, 2016.
[21] G. C. Edwards III, Implementing Public Policy. Washington, D.C.: Congressional Quarterly Press, 1980.

[22] R. Nugroho, Public Policy, no. 4. Jakarta: PT Elex Media Komputindo, Kelompok Gramedia, 2012.

[23] Food and Agriculture Organization of the United Nations (FAO), "Manual on Deforestation, Degradation, and Fragmentation Using Remote Sensing and GIS," Rome, 2007.

[24] Menteri Kehutanan Republik Indonesia, P.30/MenhutII/2009 Tentang Tata Cara Pengurangan Emisi Dari Deforestasi dan Degradasi Hutan (REDD). Menteri Kehutanan Republik Indonesia, 2009.

[25] G. B. Indrarto et al., "The context of REDD+ in Indonesia: Drivers, agents and institutions," Bogor, 2012.

[26] S. A. Abood, J. S. H. Lee, Z. Burivalova, J. Garcia-Ulloa and L. P. Koh, "Relative Contributions of the Logging, Fiber, Oil Palm, and Mining Industries to Forest Loss in Indonesia," Conserv. Lett., vol. 8, no. 1, pp. 58-67, 2015.

[27] S. Ekawati, K. Budiningsih, and G. K. Sari, "Forest Policy and Economics Policies affecting the implementation of REDD + in Indonesia (cases in Papua , Riau and Central Kalimantan)败,” For. Policy Econ., no. September 2018, pp. 1-15, 2019.

[28] B. van Hensbergen, "Forest Concessions - Past Present and Future?," Rome, 2016.

[29] J. A. Gray, Forest Concession Policies and Revenue Systems: Country Experience and Policy Changes for Sustainable Tropical Forestry. Washington, D.C.: The World Bank, 2002.

[30] Y. Meta, "Efektivitas Implementasi Pemberian Izin Pemanfaatan Air (IPA) Di Kawasan Taman Nasional Gunung Halimun Salak (TNGHS),” Institut Pertanian Bogor, 2018.

[31] R. N. Dwijowijoto, Kebijakan Publik: Formulasi, Implementasi, dan Evaluasi. Jakarta: PT. Elex Media Komputindo, 2003.

[32] H. N. Tangkilisan, Manajemen Publik. Jakarta: Grasindo, 2005.

[33] J. Widodo, Analisis Kebijakan Publik. Malang: Bayumedia Publishing, 2011.

[34] BPS-Statistics Indonesia, Statistik Indonesia (Statistical Yearbook of Indonesia) 2018. Jakarta: Badan Pusat Statistik/BPS-Statistics Indonesia, 2018.

[35] SK.782/Menhut-II/2012 Tentang Perubahan Atas Keputusan Menteri Kehutanan dan Perkebunan Nomor 891/Kpts-II/1999 Tentang Penunjukan Kawasan Hutan Di Wilayah Provinsi Daerah Tingkat I Irian Jaya Seluas 42.224.840 Hektar. Menteri Kehutanan Republik Indonesia, 2012.

[36] H. Hidayat and S. Yamamoto, "Papua's Threatened Forests: Conflict of Interest Government versus Local Indigenous People," South Pacific Stud., vol. 34, no. 2, pp. 71-98, 2014.

[37] S. N. Kartikasari, A. J. Marshall, and B. M. Beehler, Eds., Seri Ekologi Indonesia, Jilid IV: Ekologi Papua. Jakarta: Yayasan Pustaka Obor Indonesia dan Conservation International, 2012.

[38] M. Saunders, P. Lewis, and A. Thornhill, Research Methods for Business Students, $5^{\text {th }}$ ed. Prentice Hall, 2009.

[39] P. Irawan, Penelitian Kualitatif dan Kuantitatif untuk Ilmu-Ilmu Sosial. Jakarta: Universitas Indonesia, 2006.

[40] D. Murdiyarso, S. Dewi, D. Lawrence, and F. Seymour, "Indonesia's forest moratorium: A stepping stone to better forest governance?," CIFOR, Bogor, 2011.

[41] D. Zulkarnain, "Implikasi Inpres Penundaan Pemberian Izin Baru dan Penyempurnaan Tata Kelola Hutan Alam Primer dan Lahan Gambut Terhadap Kegiatan Pendaftaran Tanah (Studi Kasus: Provinsi Kalimantan Barat)," Universitas Gadjah Mada, 2016.

[42] A. J. Glauber et al., "Kerugian dari Kebakaran Hutan Laporan Pengetahuan Lanskap Berkelanjutan Indonesia," Jakarta, 2016. 
22 | Jurnal Planoearth | Vol. VI, No. II, Februari 2021, hal 7-22

[43] M. Kamuzinzi, "When traditional principles bring coherence in complex networks management: the case of 'Imihigo' in public policy implementation," Policy Stud., pp. 1-19, Feb. 2019.

[44] F. Fischer, G. J. Miller, and M. S. Sidney, Eds., Handbook of Public Policy Analysis: Theory, Politics, and Methods, 1st ed. Boca Raton, Florida: CRC Press, Taylor \& Francis Group, 2007.

[45] K. Austin et al., "Indonesia's forest moratorium: impacts and next steps," World Resour. Inst. Work. Pap., no. January 2014, pp. 1-15, 2014. 